\title{
Investigating Student's Needs for English Language as Foundations for Syllabus Design
}

Elsa Zela

Agricultural University of Tirana, Albania

Doi: 10.2478/ajis-2018-0028

\begin{abstract}
Efforts to integrate into the European Union and a rapid economic growth in Albania have led to the growing prevalence of English language, which has become the leading foreign language for communication between experts not only at the international but also national level, as various business documents, contracts, reports, etc., have been widely used by graduates in the field of economics in their daily work. Thus, English language teaching in universities should reflect these changes that are taking place extensively in Albanian society. New syllabuses should put more emphasis on the new skills that current students of economics need to be integrated into the labour market. Through semistructured questionnaires administered to 420 students of the first year studying Business English at the Faculty of Economics and Agribussines, Agricultural University of Tirana, this study aims at identifying their needs for language and communication for future use either for employment or further education purposes. Program design and course development of Business English needs to respond to future student needs for future employment or study purposes. In general, needs analysis plays a key role and is the first step in the process of drafting each subject in the English Language for Specific Purposes, a course characterized by the student centered approach. The results of this study will serve as input to be taken into account for the design of the Business English course at the Faculty of Economics at AUT. The analysis of the research data has provided teachers insights into business English teaching related issues and an essential input in BE syllabus design.
\end{abstract}

Keywords: English for Specific Purposes, Needs analysis, Target situation analysis, Learning situation analysis, Present situation analysis

\section{Introduction}

Needs analysis is the starting point of every course and is of utmost importance for ESP course design. CEFR encourages the parties involved in language learning "to base their work on the needs, motivations, characteristics and resources of the students", and this means that they should answer these three questions:

"What will the learner need to do with language?", "what do students need to learn in order to be able to use the language to achieve these goals?" and "what does they want to learn?".

Many efforts made to increase workforce engagement in English are not coordinated with the education system, are not really in line with job requirements, and not enough in their objectives and the quality offered (CEFR, 2001).

Needs are classified as necessities, wants and lacks (Hutchinson and Waters, 1987), objective and subjective or process-oriented or product-oriented (Brindley, 1989); and perceived or felt (Berwick, 1989). However, Dudley-Evans and St John (1998), further divided it into three larger categories: a target situation analysis (TSA, including objective, perceived and product-oriented needs); a learning situation analysis (LSA, including subjective, felt and process-oriented needs); 
and a present situation analysis (PSA, including learners' present levels of knowledge and skills).

Needs analysis conducted before a course works for teachers in setting teaching goals, selecting teaching content and materials, and exploring approaches of teaching and learning. Besides, it is a learner-centered approach, which is believed to stimulate learners' interest of learning to a large extent and show respect to the active role of learners in processes of learning. Furthermore, courses which are based on the findings of pre-course needs analysis will surely meet the needs of both language learners and employers.

\section{Methodology and Objective of the Study}

This study aims at examining the TSA, LSA and PSA of students studiying Business English at Agricultural University of Tirana, Albania. Questionnaire is to be used as a major instrument for collecting the data from 420 student from faculty of Economics and Agri-bussines. The questionnaire was based on the model of Dudley-Evans and St John (1998) on need analysis.

This model can be seen as the most comprehensive model for the study of ESP needs. This model focuses on:

a. professional information on students (tasks and activities during which students will use English, language analysis of the target situation (TSA) and the objective needs);

b. personal information about students (overall student profile, previous experience of learning the language);

c. language information on students about the target situation(what are their current skills and the use of language);

d. students' "lacks"( the gap between $(C)$ and $(A)$;

e. students' needs from the course (effective ways to learning skills and language);

f. the language learning needs (knowledge on how language and skills are used in targeted situations, linguistic analysis, discourse analysis and genre analysis);

g. information on communication in the target situation (students' needs from the course, what is required from the course?), and

h. the information on learning environment (condition of the learning environment, information about the setting in which the course will run- means analysis).

The paper aims at answering the following questions:

Research question no. 1: What is the current level of language skills and communication skills in the English language of students at the Faculty of Economics and Agribusiness at the Agricultural University of Tirana?

Research question No. 2: What are the learning difficulties, teaching aids and language learning facilities for these students?

Research question no. 3: What are the intended perceived needs for future communication for academic reasons or employment of students at the Faculty of Economics and Agribusiness at the Agricultural University of Tirana?

\section{Findings}

Firstly, the questionnaire collected information on students participating in the study. The data, which are largely quantitative, are related to the gender of the participants, the languages studied and the years for each language, the perceived or certified level for each language studied. Further the practices of communicative situations in the classroom, and the perceptions of the students concerned with their language needs in the future for study or employment purposes have been described in details. Below are the relevant tables.

\subsection{Students participating in the study}

The study included 420 students, of whom 144 were boys, 275 girls and 1 unspecified person for gender. 
Table 1: Gender of the students.

\begin{tabular}{|c|c|c|c|c|}
\hline Gender & Boys & Girls & Undetermined & Total \\
\hline No. of students & 144 & 275 & 1 & 420 \\
\hline
\end{tabular}

All students of the first year of the FEA at AUT participated in the study, where there is a nearly double the presence of girls versus boys.

\subsection{Foreign language studied}

Regarding foreign languages studied during university studies, 420 stated that they studied English. Further, from these 420 students, 180 students studied Italian, 78 French, 42 German, 30 Turkish, 18 Spanish, 6 Macedonian, 6 Greek and 6 Arabic as second and third foreign languages

Table 2: Number of students and foreign language studied

\begin{tabular}{|c|c|c|c|c|c|c|c|c|c|}
\hline Language & English & Italian & French & German & Turkish & Spanish & Macedonian & Arabic & Greek \\
\hline No of student & 420 & 168 & 78 & 42 & 30 & 18 & 6 & 6 & 6 \\
\hline
\end{tabular}

As noted from the table, all students studied English during their pre-university education. This was an expected result since for years the English language is a compulsory subject in the curricula of pre-university education, mainly starting from the third grade as well as compulsory state matura exam.

\subsection{Years of studying each foreign language}

Table 3: Number of students and years of studying foreign languages.

\begin{tabular}{|l|c|c|c|c|c|c|c|c|c|c|c|c|c|c|}
\hline \multicolumn{1}{|c|}{ No of years } & 1 & 2 & 3 & 4 & 5 & 6 & 7 & 8 & 9 & 10 & 11 & 12 & 13 & Total \\
\hline Language & & & 30 & 24 & 18 & 6 & 24 & 72 & 48 & 114 & 54 & 18 & 12 & 420 \\
\hline English & 60 & 30 & 42 & 18 & 6 & 6 & & & & 6 & & & & 168 \\
\hline Italian & 12 & 18 & & 6 & 36 & & & 6 & & & & & & 78 \\
\hline French & & 24 & & 12 & 6 & & & & & & & & & 42 \\
\hline German & 6 & 6 & 18 & & & & & & & & & & & 30 \\
\hline Turkish & 6 & 12 & & & & & & & & & & & & 18 \\
\hline Spanish & 3 & 3 & & & & & & & & & & & & 6 \\
\hline Macedonian & 6 & & & & & & & & & & & & & 6 \\
\hline Arabic & 6 & & & & & & & & & & & & & 6 \\
\hline Greek &
\end{tabular}

The study found out that the largest groups in the study related to the number of years were 10 years of study with 114 students, 8 years with 72 students and 11 years with 54 students. These data go in line with the fact that in most of the pre-university education schools English language teaching begins in the third grade of the lower cycle as mentioned above.

\subsection{Level of proficiency in foreign languages}

Data from student' responses revealed that most of them result in a level of knowledge of English B2 according to CEFR, and only 12 students with A1-A2 levels. This means, in other words, that students claim to stay above the average level of knowledge. This is an important factor in language learning for specific purposes as, as mentioned earlier in this study, students should be of advanced age and with good prior knowledge of English for general purposes, preferably at the level of Independent language user (B1-B2). 
Table 4: Level of proficiency in foreign languages, CEFR.

\begin{tabular}{|c|c|c|c|c|c|c|}
\hline Language level & A1-A2 & & B2 & C1 & $\mathrm{C} 2$ & \\
\hline Language & $A 1-A 2$ & DI & & & & Tolal \\
\hline English & 12 & 101 & 240 & 57 & 10 & 420 \\
\hline Italian & 66 & 66 & 24 & & & 156 \\
\hline French & 42 & 18 & 12 & & & 72 \\
\hline German & 30 & 6 & 6 & & & 42 \\
\hline Turkish & 6 & 6 & 18 & & & 30 \\
\hline Spanish & & 12 & & & & 12 \\
\hline Macedonian & & & 6 & & & 6 \\
\hline Arabic & 6 & & & & & 6 \\
\hline Greek & 6 & & & & & 6 \\
\hline
\end{tabular}

Not all students determined the level of knowledge regarding the third foreign language. A high level of Macedonian language is noticed compared to the years of study (1-2 years). These students belong to minority group who consider the Macedonian language as their mother tongue.

\subsection{Perceived importance of English language.}

Student perception about the importance of English language is fundamental to the study as they indirectly point out their motivation for language learning but at the same time their interest in contributing valuable data to the study.

Table 5: Students' perception on the importance of English language in the future.

\begin{tabular}{|c|c|c|c|c|}
\hline Very important & Averagely important & A little important & Not at all important & Total \\
\hline 412 & 8 & 0 & 0 & 420 \\
\hline
\end{tabular}

The data show that almost all students are of the opinion that English is very important for future ambitions.

\subsection{The intended use of English language in the future}

In this part of the questionnaire, the students declared the purpose of using the language in the future. Identifying the purpose is a step closer to the needs and as such is important in defining the objectives in language teaching as well as the definition of language tasks. Students were asked to circle all possible options and add if there were any other options unlisted questionnaires they might add.

Table 6: The purpose of using the language in the future

\begin{tabular}{|l|c|}
\hline Purpose of study & Percentage of students \\
\hline For employment in the country & $100 \%$ \\
\hline For employment opportunities abroad & $100 \%$ \\
\hline To study abroad & $89 \%$ \\
\hline To study literature & $87 \%$ \\
\hline To travel & $62 \%$ \\
\hline Other reasons, specify & $0 \%$ \\
\hline
\end{tabular}

Responses indicate that there are two purposes with the same answer value $(100 \%)$, that of employment both at home and / or abroad, followed by study opportunities abroad.

\subsection{Need for English language measured in skills}

Table 7: Perceived need for skills

\begin{tabular}{|l|c|c|c|c|}
\hline Language skill & Necessary & Moderate & Little Necessary & Not Necessary \\
\hline Listening & $6 \%$ & $92 \%$ & $2 \%$ & $0 \%$ \\
\hline Speaking & $76 \%$ & $24 \%$ & $0 \%$ & $0 \%$ \\
\hline Reading & $35 \%$ & $64 \%$ & $1 \%$ & $0 \%$ \\
\hline Writing & $21 \%$ & $63 \%$ & $16 \%$ & $0 \%$ \\
\hline Interacting & $44 \%$ & $51 \%$ & $5 \%$ & $0 \%$ \\
\hline
\end{tabular}


The questionnaire data revealed that students consider speaking skill necessary with the highest of $76 \%$ and the writing as litle needed with $16 \%$. Further, listening, reading, writing and interacting skills were considered on average with $92 \%, 64 \%, 63 \%$ and $51 \%$ respectively.

\subsection{Difficulties in using sub-skills}

\subsubsection{Students' difficulties in listening}

Table 8: Students' difficulties in listening.

\begin{tabular}{|l|c|c|c|c|}
\hline Sub-skills & A lot & Averagely & A little & Not at all \\
\hline Listening to presentations, discussions & $0 \%$ & $2 \%$ & $84 \%$ & $14 \%$ \\
\hline Listening the instructions & $0 \%$ & $4 \%$ & $86 \%$ & $10 \%$ \\
\hline Following the descriptions and explanations & $0 \%$ & $0 \%$ & $84 \%$ & $16 \%$ \\
\hline Participating in trainings & $0 \%$ & $2 \%$ & $82 \%$ & $10 \%$ \\
\hline
\end{tabular}

Difficulty in listening by sub-skills results to be low for students, presenting a value of 0 in the "very difficult" evaluation. The sub-skill rated as "not at all difficult" with the highest value of $(16 \%)$ is following descriptions and explanations. Meanwhile, the highest value in the "a little difficult" column results in listening to instructions.

\subsubsection{Students' difficulties in speaking}

Table 9: Students' difficulties in speaking

\begin{tabular}{|l|c|c|c|c|}
\hline Sub-skills & A lot & Averagely & A little & Not at all \\
\hline Speaking in a formal presentation & $13 \%$ & $64 \%$ & $21 \%$ & $2 \%$ \\
\hline Speaking in an informal presentation & $11 \%$ & $59 \%$ & $25 \%$ & $5 \%$ \\
\hline Providing instructions or demonstrating a task & $9 \%$ & $66 \%$ & $21 \%$ & $4 \%$ \\
\hline Describing and giving explanations & $7 \%$ & $62 \%$ & $24 \%$ & $7 \%$ \\
\hline
\end{tabular}

Unlike listening sub- skills where students expressed in higher values as "less difficult", the subskills of speaking have a shift of values to the "moderately difficult" column. From the listed subskills, students say they encounter difficulties in holding a formal presentation with the highest value in the column (13\%). While in the column "not at all difficult" describing and giving explanation reaches the highest value by considering it as easy from the listed sub-skills.

\subsubsection{Students' difficulties in reading}

Table 10: Students' difficulties in reading

\begin{tabular}{|l|c|c|c|c|}
\hline Sub-skills & $\begin{array}{c}\text { A } \\
\text { lot }\end{array}$ & $\begin{array}{c}\text { Averagely } \\
\text { little }\end{array}$ & $\begin{array}{c}\text { Not at } \\
\text { all }\end{array}$ \\
\hline Reading e-mails, letters, faxes, memos and brief reports in detail & $0 \%$ & $14 \%$ & $23 \%$ & $63 \%$ \\
\hline Reading fast for general information in magazines and professional texts. & $6 \%$ & $24 \%$ & $21 \%$ & $49 \%$ \\
\hline $\begin{array}{l}\text { Analysis for specific points in long reports, contracts and legal documents } \\
\text { as well as technical and specific manuals. }\end{array}$ & $5 \%$ & $32 \%$ & $46 \%$ & $17 \%$ \\
\hline
\end{tabular}

Reading sub-skills have been generally regarded as "not at all difficult" for students except for analysis of particular points in long reports, contracts and legal documents, technical and specific manuals which are assessed as "a little difficult" with $46 \%$. E-mails, letters, faxes, memos and short reports are not considered "difficult" by any student.

\subsubsection{Students' difficulties in using writing sub-skills}

Sub-writing skills are considered "moderately difficult" and " difficult". Editing letters and reports of others and writing long reports and articles are considered the most difficult with $63 \%$ and $62 \%$ 
respectively. Only $3 \%$ and $2 \%$ of students have considered writing e-mails and writing letters and faxes as not at all difficult. These sub-skills also have the highest values as "moderately difficult" with $51 \%$ and $56 \%$.

Table 11: Students' difficulties in using writing

\begin{tabular}{|l|c|c|c|c|}
\hline Sub-skills & A lot & Averagely & A little & Not at all \\
\hline Writing e-mails & $19 \%$ & $51 \%$ & $27 \%$ & $3 \%$ \\
\hline Writing letters and faxes & $23 \%$ & $56 \%$ & $19 \%$ & $2 \%$ \\
\hline Writing long reports and articles & $62 \%$ & $25 \%$ & $13 \%$ & $0 \%$ \\
\hline Editing letters and reports of others & $63 \%$ & $28 \%$ & $9 \%$ & $0 \%$ \\
\hline
\end{tabular}

\subsubsection{Students' difficulties in interacting}

Table 12: Students' difficulties in interacting

\begin{tabular}{|l|c|c|c|c|}
\hline Sub-skills & A lot & Averagely & A little & Not at all \\
\hline Receiving visitors & $0 \%$ & $39 \%$ & $46 \%$ & $15 \%$ \\
\hline Visiting a company & $4 \%$ & $33 \%$ & $45 \%$ & $18 \%$ \\
\hline Participating in discussions and informal meetings & $2 \%$ & $29 \%$ & $58 \%$ & $11 \%$ \\
\hline Participating in formal meetings & $5 \%$ & $44 \%$ & $41 \%$ & $10 \%$ \\
\hline Chairing meetings & $22 \%$ & $43 \%$ & $33 \%$ & $2 \%$ \\
\hline Interviewing & $12 \%$ & $54 \%$ & $20 \%$ & $14 \%$ \\
\hline Conducting negotiations & $44 \%$ & $39 \%$ & $17 \%$ & $0 \%$ \\
\hline Making calls & $3 \%$ & $42 \%$ & $33 \%$ & $22 \%$ \\
\hline
\end{tabular}

The evaluation of interacting sub-skills results mainly with "average" and "less difficult" values. Negotiating has a higher percentage $(44 \%)$ being considered as the most difficult interacting subskill and at the same time reaching a minimum of $0 \%$ where no student has considered it difficult at all. Also, receiving visitors was assessed at $0 \%$ where none of the students said it was too difficult.

\subsection{Communicative situations during Business English classes}

Table 13: Frequency of use of communicative situations and teaching tools in the classroom

\begin{tabular}{|c|c|c|c|c|}
\hline Communicative situation & $\begin{array}{c}\text { Very } \\
\text { frequent }\end{array}$ & Frequent & Sometimes & Never \\
\hline Simulation of company presentation to clients & $0 \%$ & $0 \%$ & $82 \%$ & $18 \%$ \\
\hline Simulation of presenting a product or service to clients & $0 \%$ & $0 \%$ & 81 & 19 \\
\hline Simulation of participation and chairing meetings as well as negotiating with clients & $0 \%$ & $0 \%$ & $0 \%$ & $100 \%$ \\
\hline $\begin{array}{l}\text { Discussion on various topics on aspects of the economics (marketing, accounting, } \\
\text { services, policies) }\end{array}$ & $0 \%$ & $34 \%$ & $54 \%$ & $12 \%$ \\
\hline Simulation of telephoning (search for information, analysis report, feedbreak, fixing a date, etc.) & $0 \%$ & $0 \%$ & $25 \%$ & $75 \%$ \\
\hline Interview simulation & $0 \%$ & $0 \%$ & $16 \%$ & $84 \%$ \\
\hline Conducting written inquiries / requests / complaints & $0 \%$ & $0 \%$ & $12 \%$ & $88 \%$ \\
\hline Text translation & $84 \%$ & $16 \%$ & $0 \%$ & $0 \%$ \\
\hline Summary of the text & $77 \%$ & $23 \%$ & $0 \%$ & $0 \%$ \\
\hline Doing class tasks with matching / filling in / options, etc. & $90 \%$ & $10 \%$ & $0 \%$ & $0 \%$ \\
\hline Reading compulsory text & $90 \%$ & $10 \%$ & $0 \%$ & $0 \%$ \\
\hline Reading and understanding articles, websites. & $0 \%$ & $0 \%$ & $74 \%$ & $26 \%$ \\
\hline Writing reports and memos & $0 \%$ & $0 \%$ & $0 \%$ & $100 \%$ \\
\hline Writing instructions & $0 \%$ & $0 \%$ & $0 \%$ & $100 \%$ \\
\hline Filling in an application form and / or CV & $0 \%$ & $0 \%$ & $65 \%$ & $35 \%$ \\
\hline Using Audio and / or video in the field of economics & $0 \%$ & $0 \%$ & $71 \%$ & $29 \%$ \\
\hline Authentic texts taken from real life in the context of & $0 \%$ & $0 \%$ & $35 \%$ & $65 \%$ \\
\hline
\end{tabular}

It is evident from the data that speaking and writing communication situations are almost never or rarely encountered in teaching activities. Meanwhile, most frequent are the reading of the text, its summary, the translation and doing class tasks with matching / filling in / options, etc. which mainly 
check the vocabulary with $90 \%, 77 \%, 84 \%$ and 90 respectively. It is clear that teaching focuses mainly on form (ie grammar, vocabulary, pronunciation) and not on functions (ie, communication acts). Also the writing sub-skill of communication situations of writing reports, memos, and instructions is never encountered during the teaching activity.

\subsection{Need for future communication (analysis of target situation)}

Table 14: Students perception on the needs for future communication.

\begin{tabular}{|c|c|c|c|c|}
\hline Communicative situation & Necessary & Average & \begin{tabular}{|c|} 
Little \\
necessary \\
\end{tabular} & $\begin{array}{c}\text { Not at all } \\
\text { necessary }\end{array}$ \\
\hline Presenting the company to clients & $55 \%$ & $30 \%$ & $15 \%$ & $0 \%$ \\
\hline Introducing a product or service to clients & $51 \%$ & $33 \%$ & $16 \%$ & $0 \%$ \\
\hline Taking part and conducting meetings as well as negotiating with clients & $42 \%$ & $44 \%$ & $14 \%$ & $0 \%$ \\
\hline $\begin{array}{l}\text { Conversation with colleagues on different aspects of the economics field (various } \\
\text { areas, services, company actions) }\end{array}$ & $56 \%$ & $41 \%$ & $3 \%$ & $0 \%$ \\
\hline Telephoning (search for information, report analysis, feedback, fixing appointments, etc.) & $66 \%$ & $34 \%$ & $0 \%$ & $0 \%$ \\
\hline $\begin{array}{l}\text { Socializing in Business Situations: small talk in business fair, before meetings / } \\
\text { Interview / negotiations }\end{array}$ & $57 \%$ & $37 \%$ & $6 \%$ & $0 \%$ \\
\hline Conducting written inquiries / requests / complaints & $15 \%$ & $60 \%$ & $25 \%$ & $0 \%$ \\
\hline Reading and understanding articles, web pages & $20 \%$ & $47 \%$ & $33 \%$ & $0 \%$ \\
\hline Text translation & $12 \%$ & $36 \%$ & $52 \%$ & $0 \%$ \\
\hline Writing reports and memos & $2 \%$ & $45 \%$ & $53 \%$ & $0 \%$ \\
\hline Writing instructions & $3 \%$ & $45 \%$ & $52 \%$ & $0 \%$ \\
\hline Filling in an application form and / or CV & $30 \%$ & $58 \%$ & $12 \%$ & $0 \%$ \\
\hline
\end{tabular}

Students considered "neecessary" communication situations involving sub-skills of speaking, as "averagely necessary" situations that include reading sub- skills and as "little necessary" writing sub- skills. None of the communication situations has been considered as " not at all necessary "

\subsection{Selecting three situations for immediate improvement.}

At this point in the questionnaire, students were asked to determine the three situations they would like to improve as quickly as possible keeping in mind a target situation where they would use the language.

Table 15: Situations selected for immediate improvement

\begin{tabular}{|c|l|c|}
\hline No & Communication situation & $\begin{array}{c}\text { Percentage } \\
\text { of students }\end{array}$ \\
\hline 1 & Chairing and participating meetings as well as negotiations with clients & $50 \%$ \\
\hline 2 & Presentation of the company to the clients & $46 \%$ \\
\hline 3 & Writing reports and memos & $17 \%$ \\
\hline 4 & Conversation with colleagues on different aspects of the economics (various areas, services, company actions) & $16 \%$ \\
\hline 5 & Introducing a product or service to customers & $15 \%$ \\
\hline 6. & Socializing in business situations: small talk in business fairs, before the meeting / interview / negotiations & $12 \%$ \\
\hline 7. & Doing written inquiries / requests / complaints & $10 \%$ \\
\hline 8 & Telephoning (search for information, report analysis, feedback, leaving appointments, etc.) & $9 \%$ \\
\hline 9 & Writing instructions & $9 \%$ \\
\hline 10. & Filling in an application form and / or CV & $6 \%$ \\
\hline 11 & Reading and understanding articles, web pages, marketing texts etc, for professional purposes & $3 \%$ \\
\hline
\end{tabular}

Data on communicative situations that students think they need to improve quickly show almost the same value with the perceived situations as needed in the future. Thus, $50 \%$ and $46 \%$ of students said they needed to improve their skills in situations where chairing and participation of meetings, customer negotiations and the presentation of the company to clients were required. The largest number of communication situations is related to speaking and interaction skills, while on the other hand the least selected number of situations for improvement is that of reading and writing. 


\subsection{Expectations from Business English course.}

Table 16: Students expectations from BE course

\begin{tabular}{|l|c|}
\hline Expectation & $\%$ of students \\
\hline To understand Business English terminology & $53 \%$ \\
\hline To gain the best communication skills & $32 \%$ \\
\hline To improve the spoken skills & $30 \%$ \\
\hline To understand conversation of people working in the field of economics & $6 \%$ \\
\hline To read professional articles and give feedback & $6 \%$ \\
\hline To face work situations in the future & $6 \%$ \\
\hline To improve essay writing & $5 \%$ \\
\hline To improve memos writing & $4 \%$ \\
\hline To improve communication in everyday life & $2 \%$ \\
\hline To have better knowledge in grammar & $1 \%$ \\
\hline To get a high mark & $1 \%$ \\
\hline
\end{tabular}

It is noticed from the responses that more than half of the students state that the main expectations from the course are the acquisition of Business English terminology. These data contradict the student's thinking about the situations needed for the future where they declare that communication situations are more important and useful for employment or study opportunities. Consequently, these expectations from the course are due to the classroom practice which, as noted above, consists mainly of translation and reading. At the end of the list of expectations are improving the knowledge in grammar and obtaining a higher mark with $1 \%$ of the students expressed with this option.

\subsection{Duration of the course}

Scheduling classes for the course is important. Students have BE 2 classes (60 minutes) a week with a total of 60 classes per academic year. Students were asked if these classes were enough, less than what they needed or more.From the answers provided, 222 students said that 2 classes of 60 minutes per week were sufficient. 198 of them declared that it was not enough and among them 110 think that 4 classes would be needed and 80 would think 3 classes a week would be appropriate.

Table 17: Students' suggestions for the course

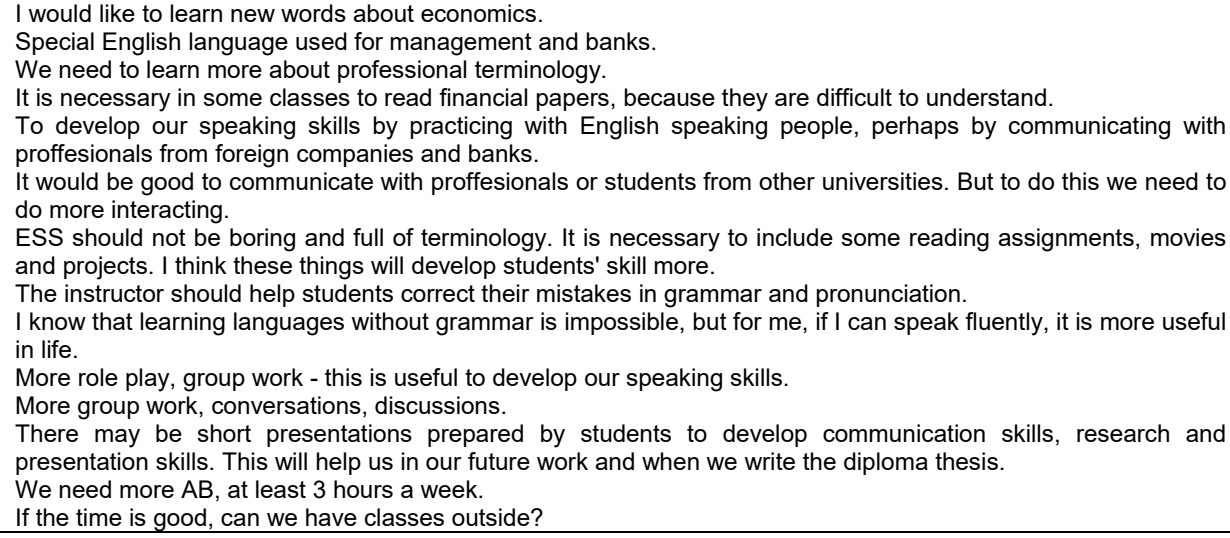




\section{Conclusion}

Based on the research questions set out earlier in this paper, this study came to the following conclusions:

\subsection{Students' current and perceived need for communication in English language .}

Students at the Faculty of Economics and Agribusiness at the Agricultural University of Tirana consider the BE subject very important in meeting their needs. Since their level of knowledge is average, their needs for language are toward skills which enable them to increase the competence of communication in the language. They stated that the main purpose for studying BE was for further studies and employment abroad. The study highlighted a greater tendency for languages for professional communication aimed at employement purposes rather than English language for academic purposes in student needs.

\subsection{Perceived target needs for future communication.}

Of the five language skills, students appreciated the need for speaking skills and the ability to write in the future. Meanwhile listening, reading, writing and interacting were considered as needed on average. In relation to communication situations, tasks such as: telephoning (requesting information, report analysis, feedback, etc.), socialization in business situations (small talk at business fairs, before the meeting / interviewing / negotiating) etc., are "necessary", while situations involving sub-skills of reading are considered as "averagely necessary" and the sub-writing skills were determined as "a little necessary" The largest number of communication situations required for improvement is related to speech and interaction skills, while on the other hand, the least selected number of situations for improvement is that of reading and writing.

\subsection{Difficulties in learning, teaching aids and learning environments.}

Students encounter average difficulty in using writing, speaking and interacting skills, while reading and listening are considered to be a bit difficult. Using writing skills is considered to be very difficult. ESP language teaching practices in class are not conducted by having the student centered and continue in the traditional teaching approach of form and vocabulary and not into functions, the student's tasks, and goals for learning a foreign language. Thus, from the communication skills of the language, the data clearly show that communicative speech and writing situations are rarely encountered or never in the teaching activities. Meanwhile, the highest values with greater frequency are exercises that mostly check vocabulary.

The audio-visual aids are not used in the classroom neither are additional authentic teaching materials while classes focuse on basic compulsory texts and accompanying grammar that are prepared for non-native speakers.

\section{References}

Berwick, R. (1989). Needs assessment in language programming: fro theory to practice. In : Johnson, R. K. (Ed). The second language curriculum (p .48-62). Cambridge: Cambridge University Press.

Brindley, G. (1989). The role of needs analysis in adult ESL program design. In: Johnson, R .K. (Ed). The second language curriculum (p.63-78). Cambridge: Cambridge University Press.

Common European Framework of languages, 2001. https://www.coe.int/t/dg4/linguistic/Source /Framework_EN.pdf

Dudley-Evans, T. \& St. Johns, (1998) Developments in AQS: A multidisciplinary approach. 4th ed. Cambridge: Cambridge University Press.

Gatehouse, K., 2001. "Key Issues in English for Specific Purposes (ESP)", Curriculum Development", The Internet TESL Journal, 7(10), available at: http://iteslj.org/Articles/Gatehouse_ESP.html.

Graves, K. (2000). Designing language courses: A guide for teachers. Boston: Heinle and Heinle Thomson Learning 
Hutchinson,T. and Waters, A. (1987). English for Specific Purposes: A learning-centred approach. Cambridge: Cambridge University Press.

International Teacher Training Organization. EFL Teaching terminology and glossary. (2005). Available at: http://www.teflcertificatecourses.com/tefl-articles/eflteaching-terminology.html. 